\title{
Effect of bottom sediments on the nutrient and metal concentration in macrophytes of river-lake systems
}

\author{
Angela Kuriata-Potasznik ${ }^{1, *}$, Sławomir Szymczyk ${ }^{1}$ and Dorota Pilejczyk ${ }^{2}$ \\ ${ }^{1}$ Department of Water Resources, Climatology and Environmental Management, University of Warmia and Mazury in Olsztyn, \\ Plac Łódzki 2, Olsztyn 10-719, Poland \\ ${ }^{2}$ Department of Agricultural Chemistry and Environmental Protection, University of Warmia and Mazury in Olsztyn, \\ ul. Oczapowskiego 8, Olsztyn 10-719, Poland
}

Received: 19 May 2017; Accepted: 13 November 2017

\begin{abstract}
Water bodies of river-lake systems can act as barriers in the movement of nutrients and toxic heavy metals outside their water catchment area. These components can be suspended in the water column, deposited in bottom sediments or bioaccumulated by the vegetation in the water body. A constant exchange of substances takes place between bottom sediments and macrophytes. The composition of bottom sediments and their distribution affects the intensity of nutrients and metals assimilation by macrophytes in the river-lake systems. The aim of research was to analyse the effect of bottom sediments on the nutrients and metal content in macrophytes. It was demonstrated that tissues of plants anchored in sediments that were more abundant in nutrients had higher contents of biogenic components and heavy metals. The properties of bottom sediments, mainly their granulometric composition, but also organic matter content and $\mathrm{pH}$, determine the content of biogenes and heavy metals in macrophytes to a significant extent. On the other hand, it was demonstrated that aquatic plants could affect the grain size in the sediments. Macrophytes and sediments of river-lake systems play a very important role in reducing the transport of nutrients outside the area of the system, through capturing and incorporating them into the tissues of aquatic plants.
\end{abstract}

Keywords: macrophytes / river-lake system / bottom sediments / heavy metal / nutrient

\section{Introduction}

River-lake systems create chains of lakes connected by rivers flowing through the water body. Water bodies situated along the river course can act as barriers to the matter entering them (and for its transformation or accumulation) or accumulate matter flowing into them from the neighbouring areas or transport matter out along the river (Glińska-Lewczuk, 2005,2006 ). The progress in degradation of river-lake systems is demonstrated by an increase in the water trophic status (Potasznik and Szymczyk, 2016). Water bodies functioning in river-lake systems, unlike holding water bodies, are characterized by varied morphology and various trophic states in individual parts of the water body, which leads to their uneven degradation (Duarte and Kalff, 1988). The use of macrophytes to evaluate the degradation of the ecological condition permits determining the correlation between the biotope quality and the quality of biocenos in surface waters. Biomonitoring permits estimating the quality of surface waters in lakes, based

\footnotetext{
*Corresponding author: angela.potasznik@uwm.edu.pl
}

on the existence of specific species of plant communities, their range and ability to accumulate nutrients and heavy metals (Duarte and Kalff, 1988).

Macrophytes, being hydrophilic plants, make up an element of rush and swamp systems fulfilling different functions in the environment, for instance:

- they are characterized by a high ability to assimilate biogenic elements and provide a habitat for living organisms (Wang et al., 2013); their assimilative abilities are comparable with the abilities of wetlands (Huang et al., 2015). Such species as Phragmites australis and Typha latifolia make the vertical substrate for a wide group of organisms, with all trophic levels (producers, decomposers and consumers) (Obolewski, 2005). Reeds are more resistant to overgrowth than bulrush (Obolewski, 2002). This phenomenon is determined by the availability of light, temperature, waves, the type of substrate and the water quality (Obolewski et al., 2011);

- their species composition can reflect the degree of the water body eutrophication and can affect the development of environmental conditions, regulating the intensity of light reaching the water body or species composition of its fauna 
(Carvalho et al., 2015). Reeds demonstrate high potential to improve water quality (Lakatos et al., 1999). This is a species that is most resistant to varied environmental conditions and which occurs commonly all over the world (Du et al., 2006);

- they also affect the accessibility of oxygen in surface and interstitial water through the processes of photosynthesis, respiration and decomposition (Huang et al., 2015);

- their presence affects the metabolism in bottom sediments (Wang et al., 2013), organic matter content and oxygen release from sediments (Wang et al., 2013);

- their underground parts play a stabilizing function for substrate layers situated near the surface and take up nutrients from sediments located at the bottom (Jin et al., 2016);

- macrophytes are rooted in the bottom, but they are also present in the entire water column, rising above the water surface in the littoral zone (Li et al., 2014);

- they play an important role in the ecosystem structure and participate in cleaning the water in shallow lakes (Yu et al., 2015).

On the other hand, bottom sediments are also responsible for the circulation of elements in the ecosystem (Czamara and Czamara, 2008) and their specific properties determine occurrence of particular species of aquatic plants (Szmeja, 2006). The structure of bottom sediments can be a factor preventing the development of submerged macrophytes (Szafran, 2003). The growth of rush plants depends, among others, on the abundance of bottom sediments in macro- and micro-components (Pachuta and Oglęcki, 2001). Plants take up those components from water and sediments and those accumulated at the bottom can be picked up and suspended in the water depth as a result of the re-suspension process. This process is determined by the sediment structure. Water movement more easily picks up small diameter particles (Parsons et al., 2017). Additionally, the process can be affected by the redox potential of the sediments, oxygen content at the very bottom, temperature, type of chemical compounds and the level of sediment hydration (Bartoszek, 2007). Depending on the fertility of the substrate and its chemical composition, plants of various types can occur and some of those species are characterized by a broad tolerance for those factors (Wesołowski et al., 2001; Pełchaty and Promin, 2015).

The research hypothesis assumes that assimilation of nutrients and heavy metals by individual species of aquatic plants found in river-lake systems was affected mainly by the properties of bottom sediments, such as their granulometric composition, organic matter content and $\mathrm{pH}$. The aim of the research was to analyse the effect of bottom sediments on the content of nutrients and metals in macrophytes. This paper analysed the effect of specific properties of bottom sediments, i.e. granulometric composition, organic matter content and $\mathrm{pH}$, on accumulation of biogenes and heavy metals by specific types of aquatic plants in the river-lake system.

\section{Methodology}

The research was carried out in Lake Symsar, a flowthrough lake with an area of 135.5 ha and a maximum depth of $9.4 \mathrm{~m}$ (mean $4.7 \mathrm{~m}$ ) situated in the Olsztyn Lake district in north-eastern Poland. The water body is of the postglacial origin (finger lake). The water body from the south is entered by the Symsarna River, which flows from Lake Luterskie, then through Lakes Lawki and Blanki and leaves the water body analysed in this study, flowing in a northward direction. The course of the river flow divides the lake to into the main body of water, including its southern, western and central parts, and the bay part, situated in its northern most area (Fig. 1), beyond the main course of the river flow. The water catchment area of the lake is covered with agricultural land and forest areas, the western part of the water body features forests, with recreation areas developed with numerous holiday cottages and a beach in the northern part. Therefore, due to a differentiated water catchment area, the water body has been divided into two additional zones: a forest and recreation zone. Rush vegetation occupied about $11.8 \%$ of the entire water body coverage and the mean range of the plant occurrence was three metres. In terms of the Ecological State Macrophyte Index applied in biomonitoring as one of the biological indicators of water quality, based on the occurrence of rush vegetation, the lake was assessed as class III lake (WIOS, 2012). Six types of macrophytes were identified in the rush vegetation of Lake Symsar.

For the study purposes, conducted in 2014 in June, 12 representative shoreline belts were selected ( $30 \mathrm{~m}$ wide each) (Fig. 2), their amounts were calculated on the basis of the result of the actual number of profiles (NPA) formula for lakes with surfaces above $20 \mathrm{ha}$, or the minimum required number of transects (Jensen, 1979; Kolada and Ciecierska, 2009). Transects were located in characteristic places of the water body, such as the presence of recreation areas (points 1, 2, Fig. 2); a lake bay outside the impact area of the river flowing through the water body (3-5); the outlet of the river from the lake $(6,7)$; the inflow of the main river to the water body and a smaller water course supplied by household sewage (8-10) and the presence of forest areas $(11,12)$. In each of them $(12$ transects), all macrophyte species composition were analysed, along with the percentage coverage of the shoreline and, additionally, representative samples of the plants (stems and immersed leaves) occupying an area of about $50 \mathrm{~cm}^{2}$ were collected in order to perform physico-chemical analyses. To carry out a chemical analysis, the plant material was analysed in three replications. Samples of macrophytes $(2 \mathrm{~g})$ were weighed at air temperature and mineralized in Kjeldahl flasks, in heating blocks in an open system. In order to determine total nitrogen, samples were mineralized using a mixture of $95 \%$ sulphurous acid p.a. grade manufactured by CHEMPUR, and $30 \%$ hydrogen peroxide p.a. grade manufactured by STANLAB. The residue obtained was distilled against $0.1 \mathrm{~mol} \mathrm{~L}^{-1}$ $\mathrm{HCl}$ in distillation equipment manufactured by BÜCHI and the distillate was titrated with $0.1 \mathrm{~mol} \mathrm{~L}^{-1} \mathrm{NaOH}$. In order to analyse the content of total phosphorus (TP), calcium and magnesium, mineralisation of samples involved the use of a mixture $(1: 1, \mathrm{v}: \mathrm{v})$ of $65 \%$ nitric acid p.a. grade by CHEMPUR and $70 \%$ perchloric acid p.a. grade by STAN-LAB and the samples were mineralized at about $120^{\circ} \mathrm{C}$. The residue after mineralization was transferred through a solid filter (type 390) to $500 \mathrm{~mL}$ measuring flasks and the filtrate was filled up with distilled water.

The content of TP was determined using the colorimetric method, with ammonium molybdate and tin (II) chloride using 


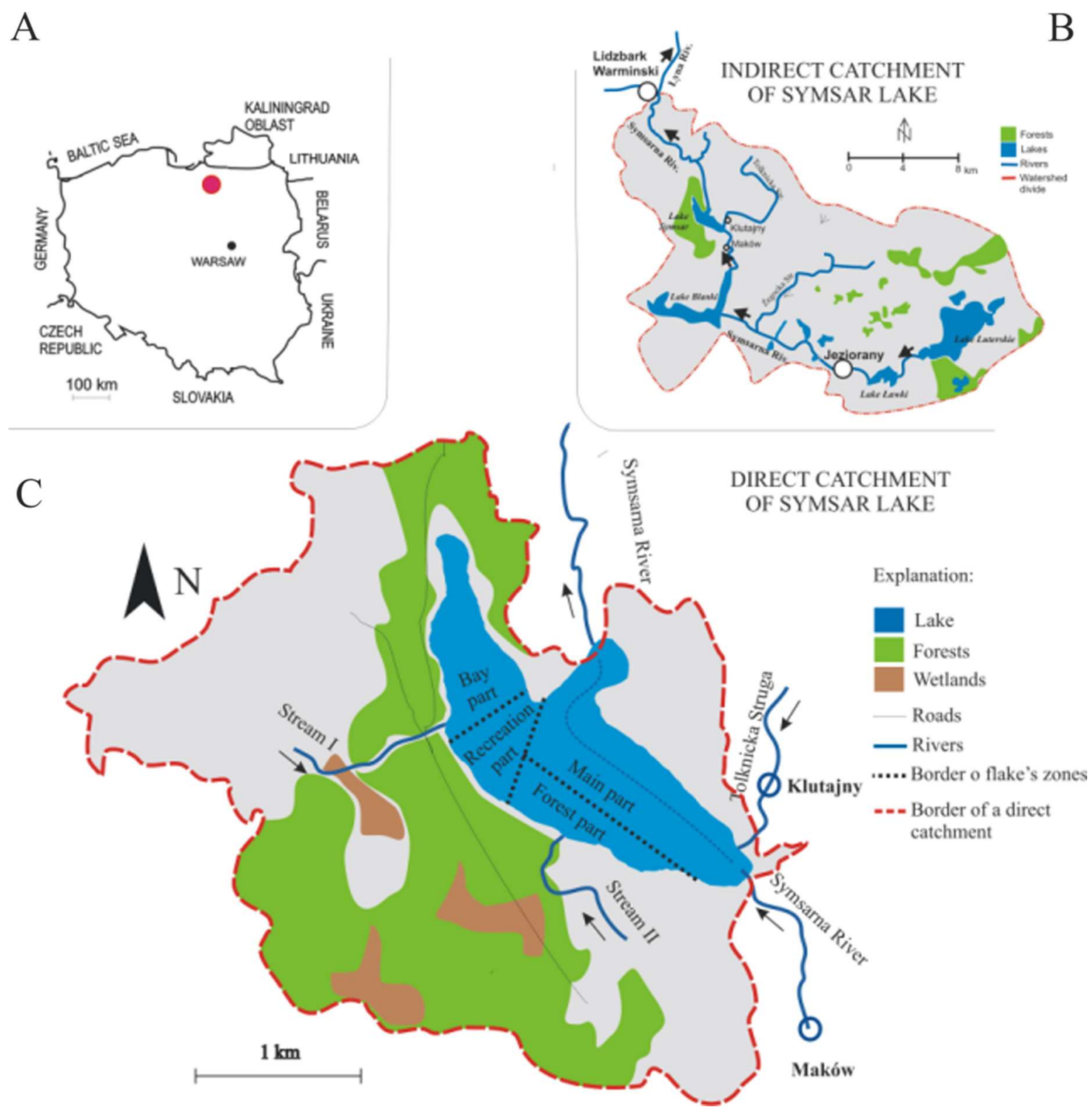

Figure 1. Location of Lake Symsar on the map of Poland (A), use of indirect water catchment area of Lake Symsar (B), use of the direct water catchment area, and the division of the water body into zones.

a spectrophotometer at $650 \mathrm{~nm}$ wave length. The content of magnesium oxide $(\mathrm{MgO})$ and calcium oxide $(\mathrm{CaO})$ was determined by titration with $0.01 \mathrm{M}$ disodium dihydrate $\left(\mathrm{C}_{10} \mathrm{H}_{14} \mathrm{~N}_{2} \mathrm{O}_{8} \mathrm{Na}_{2}\right)$ in the presence of eriochrome black and murexide. The content of $\mathrm{Mg}$ and $\mathrm{Ca}$ was expressed in $\mathrm{mg} \mathrm{kg}^{-1}$ s.m. by multiplication by 0.603 (in case of $\mathrm{Mg}$ ) and by 0.715 (in case of $\mathrm{Ca}$ ). Mineralization of samples to determine heavy metals was carried out as in the case of TP against the mixture of nitric and perchloric acids at $200{ }^{\circ} \mathrm{C}$. The analysis of a blind sample and of certified reference materials was prepared with the same reagents. About $1 \mathrm{~mL}$ residue after distillation (milky deposit and transparent residue over the deposit) was transferred to a solid filter (type 390) to $500 \mathrm{~mL}$ measuring flasks and filled up with distilled water. Concentrations of available zinc $(\mathrm{Zn})$, manganese $(\mathrm{Mn})$, iron $(\mathrm{Fe})$, chromium $(\mathrm{Cr})$, copper $(\mathrm{Cu})$, nickel $(\mathrm{Ni})$, cadmium $(\mathrm{Cd})$ and lead $(\mathrm{Pb})$ were determined in three replications in the laboratory of the Chair of Chemistry and Environmental Management of the University of Warmia and Mazury in Olsztyn, using the atomic absorption spectrophotometer (AAS6800 Schimadzu) in an air-acetylene system. The BGC-D2 (deuterium background correction) was used. External standards were used to ensure analytical quality control. A peak search was performed in the vicinity of the expected analytical lines: $\mathrm{Mn}-279.5 \mathrm{~nm}, \mathrm{Cr}-357.9 \mathrm{~nm}, \mathrm{Cu}-324.8 \mathrm{~nm}, \mathrm{Ni}-$ $232.0 \mathrm{~nm}, \mathrm{Cd}-228.8 \mathrm{~nm}, \mathrm{~Pb}-217.0 \mathrm{~nm}, \mathrm{Zn}-139 \mathrm{~nm}$. The results of the analyses of the certified reference material CRM055-50G (Sewage Sludge Certified Reference Material specified by the ISO Guides 34, 35 and ISO 17025, SIGMAALDRICH) were as follows: $693 \mathrm{mgMn} \mathrm{kg}^{-1}, 289 \mathrm{mgCr} \mathrm{kg}^{-1}$, $482 \mathrm{mgCu} \mathrm{kg}^{-1}, 163 \mathrm{mgNi} \mathrm{kg}^{-1}, 60.6 \mathrm{mgCd} \mathrm{kg}^{-1}, 154 \mathrm{mgPb}$ $\mathrm{kg}^{-1}$ and $1240 \mathrm{mgZn} \mathrm{kg}^{-1}$. The results of blind tests were as 


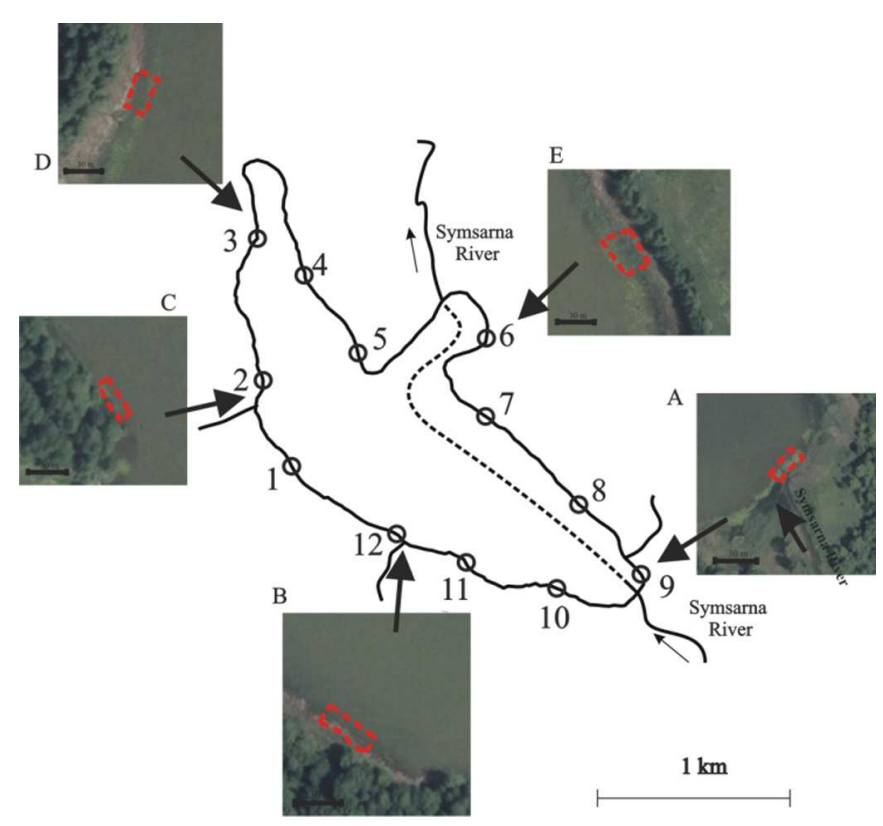

Figure 2. The location of representative $30-\mathrm{m}$ belts of macrophytes in Lake Symsar and the range of selected transects (A, B, C, D, E).

follows: $\quad 677.5 \mathrm{mgMn} \mathrm{kg}^{-1} \quad(97.8 \%), \quad 310.7 \mathrm{mgCr} \mathrm{kg}^{-1}$ $(107.3 \%), \quad 503.3 \mathrm{mgCu} \mathrm{kg}^{-1} \quad(104.4 \%), \quad 174.9 \mathrm{mgNi} \mathrm{kg}^{-1}$ $(107.3 \%), \quad 63.1 \mathrm{mgCd} \mathrm{kg}^{-1} \quad(104.0 \%), \quad 152.54 \mathrm{mgPb} \mathrm{kg}^{-1}$ $(8.1 \%)$ and $1076.2 \mathrm{mgZn} \mathrm{kg}^{-1}(86.8 \%)$ and all of them were within the acceptable range of deviation. Samples of bottom sediments (13 points) were collected from representative places of the water body, at the depth of $0-10 \mathrm{~cm}$, with the use of the Ekman grab. Air-dried sediments were ground in a mortar and analyzed to determine the physicochemical parameters such as organic matter content $\left(\mathrm{OM}, \mathrm{g} \mathrm{kg}^{-1}\right)$, by the gravimetric method, after drying at $105^{\circ} \mathrm{C}$ and incinerating in a muffle furnace at $550{ }^{\circ} \mathrm{C}$; and $\mathrm{pH}$, by the potentiometric method in $\mathrm{KCl}$ (actual and exchangeable acidity), 1:2.5 (w/v) ratio.

The significance of differences in component accumulation of macrophytes between different parts of the lake was assessed with a non-parametric analysis of variance: KruskalWallis' test $(\mathrm{K}-\mathrm{W}, p \leq 0.05)$ followed by Dunn's test as a post hoc procedure. Correlations between fractions, organic matter content (OM), $\mathrm{pH}$ and heavy metal contents were assessed with the r-Pearson correlation analysis. The response of the component content in macrophytes to the environmental conditions was analyzed using multivariate statistical analyses. Detrended correspondence analysis (DCA) and redundancy analysis (RDA) (Canoco 4.5 software package) (Ter Braak and Smilauer, 2002) were used for analyses of macrophyte abundance. DCA was used first to determine the character of variability in the studied assemblages: the length of the first gradient is greater than two standard deviations - unimodel variations, smaller than two SD - linear variations. The results of DCA indicated linear variations, providing justification for the future use of RDA. RDA was used to obtain an overview of the community level statistical significance of the canonical axes determined using a Monte Carlo permutation test. The environmental factors under analysis included: (a) location of macrophytes in the water body, with reference to the division of the examined water body into zones, (b) macrophytes species: Typha latifolia L., P. australis, Nymphaea alba L., Myriophyllum spicatum, Equisetum fluviatile L., Typha angustifolia L, (c) bottom sediment properties: granulometric content (fraction: medium sand, fine sand, very fine sand, clay, silt), $\mathrm{pH}$ and organic matter content.

\section{Results}

Macrophytes growing along the course of the Symsarna River and near the beach, i.e. in the recreational part, contained the highest amounts of total nitrogen and its phytosorption was as follows: main part $>$ recreational part $>$ bay $>$ forest. In the recreational part, rushes also accumulated phosphorus (by $39.8 \%$ more in comparison to other zones): recreational part $>$ bay $>$ forest $>$ main part (Tab. 1). Plants in the lake bay contained the highest amounts of calcium, a Eurasian water milfoil was observed in this zone, which prefers waters rich in calcium: bay $>$ recreational $>$ forest $>$ main part. On the other hand, magnesium was prevailing in plants in the forest part and also in the bay part: forest $>$ bay $>$ recreational $>$ main part.

The results of the Kruskal-Wallis test and the post-hoc test demonstrated a significant difference of lead and zinc content between plants growing in different location in the water body. The results of Dunn's test showed a statistically significant difference in lead concentration between plants growing in the bay part and the forest part (Tab. 1). A high concentration of these metals was observed in rushes of the lake bay located in the western part of the water body, near the southwest-north communication route.

In tissues of common reed, $P$. australis, the most frequent plant in the water body, performed mainly cadmium, while in other plant species under analysis the concentrations of this metal was below the level of determination (Tab. 2). As regards heavy metals in tissues of the reedmace, Typha latifolia L., high concentrations of nickel and chromium were observed. As it has already been mentioned, it grew mainly in the bay part. On the basis of the research conducted, it was found that the common water lily plants, $N$. alba L., demonstrated a high ability to absorb nitrogen and phosphorus, while in the tissues of Eurasian water milfoily, M. spicatum, performed mainly calcium and magnesium and, as regards metals, also copper, nickel, chromium, zinc and manganese. In tissues of reedmace, Typha angustifolia L., were observed mainly high concentrations of lead. On the other hand, the horsetail, E. fluviatile L., occurring at the shore covered by the forest, concentrations of calcium and magnesium were highest than in tissues of other species, but also nitrogen and, as far as metals are concerned, manganese (Tab. 2).

The RDA was carried out on the basis of the nutrient content in macrophytes of the tested water body, i.e. total nitrogen, TP, calcium and magnesium, the content of heavy metals: cadmium, copper, lead, nickel, chromium, zinc, manganese and environmental variables, i.e. the location of plants in the water body, their species and properties of bottom sediments: fraction, $\mathrm{pH}$ and organic matter (Figs. 3 and 4). The RDA analysis (Figs. 3 and 4, Tab. 3) showed that component content in macrophytes was highly correlated with the first components (axis $1-46.2 \%$ of value). On the other hand, the second axis showed moderately low correlation $(2.7 \%$ of 
Table 1. The concentration of individual components: nutrient and metal $\left[\mathrm{g} \mathrm{kg}^{-1}\right]$, organic matter [\%] and granulometric fraction [\%] with reference to the location of macrophytes in the water body.

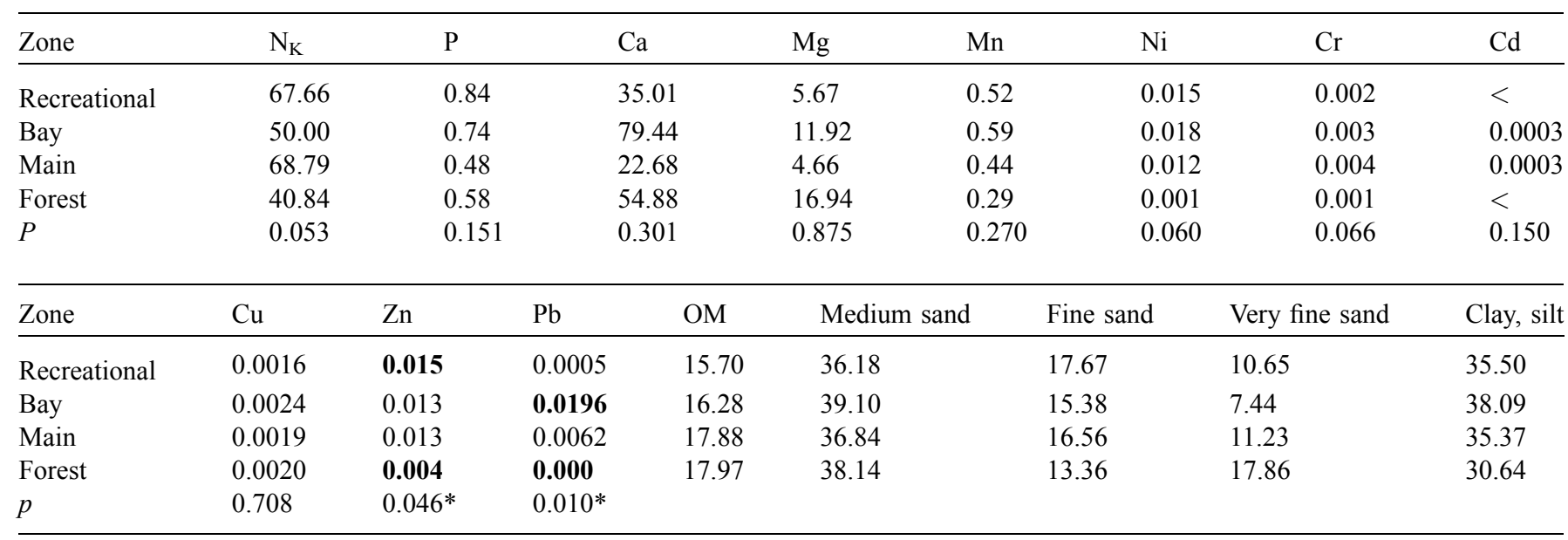

Table 2. Concentration of individual components $\left[\mathrm{g} \mathrm{kg}^{-1}\right]$ by species of plants in Lake Symsar.

\begin{tabular}{llllllllllll}
\hline Species & $\mathrm{N}_{\mathrm{K}}$ & $\mathrm{P}$ & $\mathrm{Ca}$ & $\mathrm{Mg}$ & $\mathrm{Mn}$ & $\mathrm{Ni}$ & $\mathrm{Cr}$ & $\mathrm{Cd}$ & $\mathrm{Cu}$ & $\mathrm{Zn}$ & $\mathrm{Pb}$ \\
\hline Typha latifolia L. & 68.96 & 0.47 & 27.92 & 4.42 & 0.55 & 0.024 & 0.0032 & $<$ & 0.0025 & 0.019 & 0.010 \\
Phragmites austalis & 54.50 & 0.70 & 22.77 & 2.79 & 0.32 & 0.007 & 0.0034 & 0.0002 & 0.0013 & 0.008 & 0.002 \\
Nymhaea alba L. & 86.00 & 1.02 & 43.09 & 11.09 & 0.51 & 0.003 & 0.0010 & $<$ & 0.0009 & 0.013 & 0.000 \\
Myriophyllum spicatum & 42.22 & 0.87 & 237.24 & 42.77 & 1.19 & 0.024 & 0.0039 & $<$ & 0.0042 & 0.020 & 0.006 \\
Typha angustifolia L. & 39.26 & 0.73 & 44.83 & 0.79 & 0.54 & 0.023 & 0.0036 & $<$ & 0.0033 & 0.010 & 0.015 \\
Equisetum fluviatile L. & 43.45 & 0.66 & 95.83 & 33.09 & 0.41 & 0.003 & 0.0014 & $<$ & 0.0016 & 0.005 & 0.000 \\
p & 0.414 & 0.439 & 0.795 & 0.128 & 0.169 & 0.253 & 0.690 & 0.546 & 0.351 & 0.196 & 0.234 \\
\hline
\end{tabular}

Denotations: $\mathrm{n}=18, \mathrm{p}-$ results of Kruskal-Wallis test,$<-$ value below detection limits.

value). On the basis of the RDA, a close relationship is observed between the clay, silt content in sediments and the total nitrogen concentration in tissues of rush plants, particularly in the bay zone and along the course of the Symsarna River. Fractions of very fine and medium sand were correlated with $\mathrm{pH}$ of sediments and the organic matter content. Lead and zinc were reversely correlated with plant location in the water body with high contents of the examined components present in tissues of the bay plants (Fig. 3). A comprehensive tool in the description of relationship between contents of analysis components (species and environmental variables) is RDA with forward selections with Monte Carlo permutation test. Based on analysis of gradients related to first and second components, one may conclude that the variance explained between concentrations of nutrients, metals and environmental variables is high and amounts to $74.4 \%$ and $56.4 \%$, respectively. The relations are the strongest between location and $\mathrm{Cd}, \mathrm{Cr}$ and $\mathrm{Pb}$ content in macrophytes (Fig. 3). Cadmium and chromium were prevailing in zones within the reach of the Symsarna River and the bay (Fig. 3, Tab. 1), mainly in tissues of $P$. australis, most abundantly occurring in those zones. On the other hand, lead was present mainly in the bay part, where its content observed in plant tissues was eight times higher than in any other zone (Fig. 3, Tab. 1). Additionally, an environmental factor, such as the species, demonstrated a similar gradient in relation to calcium (Fig. 4); this component was present mainly in the tissues of $M$. spicatum (with almost five times higher content than in tissues of other plants, Tab. 2).

The RDA carried out for the most frequent species in the examined river-lake water body: $P$. australis and Typha latifolia, demonstrated that the concentrations of components, i.e. phosphorus and chromium in tissues of $P$. australis was closely correlated with the fraction of sediments (phosphorus with the finest fraction, i.e. clay, silt) while chromium was closely correlated with the largest fraction - medium sand.

\section{Discussion}

In this study, the research conducted concerned the bioaccumulation of nutrients and metals in aquatic plant in river-lake system as an effect of properties of bottom sediments.

The accumulation of metals in this species could depend, among others, on the type of the water ecosystem, but also on habitat conditions of macrophytes (Obolewski et al., 2011). In the studies conducted, a organic matter content in bottom sediments possibly affecting on the concentration of nutrients and metals in reed tissues (for example the zinc content) and fraction of sediments was correlated with the concentrations of 


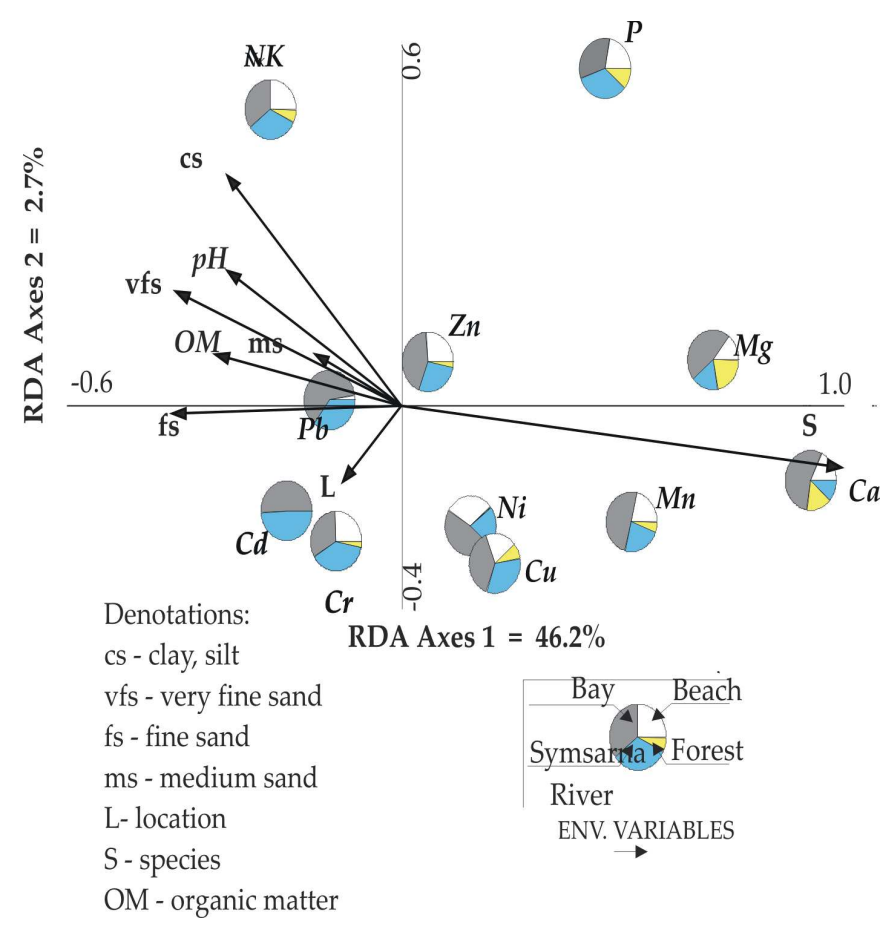

Figure 3. Ordination plot of Redundancy analysis (RDA) for component content (species) and location, macrophytes species and bottom sediments properties: $\mathrm{pH}, \mathrm{OM}$ and fraction (environmental variables). Relative value of components contents in pie classes represented by the location in lake zone.

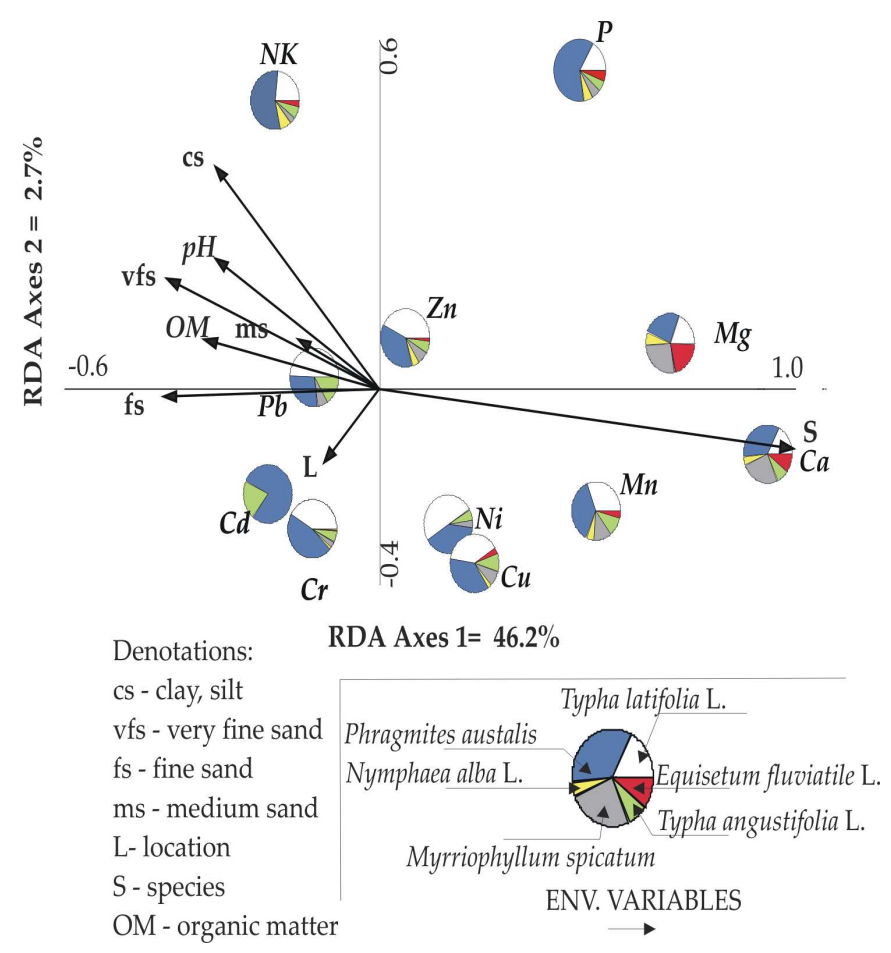

Figure 4. Ordination plot of Redundancy analysis (RDA) for component concentration (species) and location, macrophytes species and bottom sediments properties: $\mathrm{pH}, \mathrm{OM}$ and fraction (environmental variables). Relative value of components contents in pie classes represented by species of macrophytes.
Table 3. Results of ordination plot of Redundancy analysis (RDA).

\begin{tabular}{llll}
\hline Axes & 1 & 2 & Total variance \\
\hline Eigenvalues & 0.462 & 0.027 & \\
Species-environment correlations & 0.744 & 0.564 & 1.000 \\
Cumulative percentage variance & & & \\
Of species data & 46.2 & 48.9 & \\
Of species-environment relation & 91.1 & 96.4 & \\
Sum of all eigenvalues & & & 1.000 \\
Sum of all canonical eigenvalues & & & 0.507 \\
\hline
\end{tabular}

Zeszyty Naukowe Politechniki Rzeszowskiej 240: 5-21

chromium and phosphorus. The nickel content in its tissues depended on the fraction of sediments on which its plants grew, which were most frequently the finest ones. Most components are accumulated in its roots with less in rhizomes, stems and leaves (Sasmaz et al., 2008).

The uptake of substances, including metals, by the plant depends on the bioavailability of the components in water and in sediments which, in turn, depends on the metal retention time (Branković et al., 2012). The compound content in tissues of aquatic plants is quite often determined by the development of the water catchment area (biogenes and metals are carried away from the catchment area, accumulate in sediments and from there, they are assimilated by roots of aquatic plants). The presence of the communication route (municipal hard-surfaced road) not only contributed to lead accumulation in sediments neighbouring on the route (Kuriata-Potasznik et al., 2016), but also to its accumulation by nearby rushes, which was even five times higher than in rushes of other zones (particularly the species of Typha angustifolia and latifolia). Based on the results reported by Kuriata-Potasznik et al. (2016) and the results obtained in this paper, it can be concluded that plants anchored in sediments with lower levels of biogenic compounds will be characterized by lower contents of biogenic compounds in tissues. However, aquatic plants can accumulate high concentrations of toxic metals, to levels exceeding the norms for soil or sediments (Branković et al., 2012). According to Skorbiłowicz et al. (2016), the content of heavy metals in plant tissues reflects the content of metals in sediments. In turn, according to Duarte and Kalff (1988), morphometrical characteristics of water bodies, i.e. depth, exposure to wind and waves and inclination of the bottom, seem to have a greater effect on the growth of submerged macrophytes than the level of nutrients in sediments. In a study by Kisson et al. (2013), the impact of two factors on the growth of macrophytes was emphasized: the organic matter content and the size of particles in bottom sediments. The studies demonstrated a relationship between macrophytes and distribution, composition and size of sediment particles in the water environment. They are thought to play an important role in stabilization of sediments and reduce the re-suspension of sediments, bottom erosion and water turbidity. At low depths, when macrophytes occupy the entire water column, water flow intensity is reduced. At greater depths, when the water level is higher than the maximum height of the plant canopy, wave suppression is limited and the substances are suspended in water. The transport of larger particles of sediments requires higher flow rates, which are reduced by the 
presence of aquatic plant habitats. In such a case, the particles are deposited at the bottom and the growth of plants on a coarse substrate is significantly impeded (Madsen et al., 2001). Very fine particles are also difficult to erode and those fractions are characterized by the ability to retain nutrients (Kisson et al., 2013), which are assimilated by plants, resulting in their more intensive growth (Madsen et al., 2001). Kuriata-Potasznik et al. (2016) found that the content of such metals as cadmium and chromium in sediments was correlated with the presence of the fine sand fraction in those sediments. In this paper, the content of those metals was related to the location of rushes and their higher concentrations were most frequent in plants of the main part, where, according to Kuriata-Potasznik et al. (2016), very fine fractions were prevalent. In the river-lake system, near the outlet of the river into the lake, deposition of coarse fractions, such as medium sand, are observed. Along with the distance from the outlet, the strength of the water current permits transporting the carried material further on, where finer fractions are deposited (Kuriata-Potasznik et al., 2016). Outside the range of rush plants, in the bottom sediments of the profundal zone of the water body, very fine fractions of dust and loam are prevailing (Kuriata-Potasznik et al., 2016).

The finest fraction, i.e. silt and clay, was related to the nitrogen content in plant tissues. In the longer-term perspective, constant accumulation and deposition of particles may result in water opacity or shadowing of the photosynthetic surfaces, which can reduce plant growth. Additionally, plants are also nourished by nutrient transport through cracks in sediment particles, mainly sands and gravels (Madsen et al., 2001).

The effects of organic amendments in heavy metal bioavailability depend on the nature of the organic matter, their microbial degradability, salt, $\mathrm{pH}$ and redox potential, and also type of metals (Ganesh et al., 2015). Metals also have high affinity for humic, organoleptic, and organic oxides (Connell and Miller, 1984). Metal formed complexes with hydrated iron and manganese oxides, as well as with organic matter (Zerbe et al., 1999). The content of nutrients and heavy metals in sediments is dependent from organic matter decomposition, the principal role belongs submersed and floating rooted plant (Pajević et al., 2003). An increased share of organic matter in sediments is the effect of anaerobic decomposition resulting from a high level of methanogenes and methane saturation in interstitial water (Jespersen et al., 1998). Organic substances accumulate more frequently in the vicinity of macrophyte habitats than in sediments of open waters. Constant accumulation of matter is not a favourable condition for plants. According to Koch (2001) and Madsen et al. (2001) even more than $5 \%$ content of organic matter can lead to plant death. The sediments in the examined water body of the riverlake system contained up to $15.9 \%$ organic matter in the recreational part and up to $17.9 \%$ in the forest part (KuriataPotasznik et al., 2016). Disturbances in the sediment structure through resuspension seems to have a favourable effect on plants, since it reduces decomposition of matter.

Species of aquatic plants differ between each other in their anatomy, physiology, tolerance of stressors, such as flow rate, light, salinity, ice cover, temperature, content of nutrients, competitiveness and diseases. Many species adjusted to the stress factors and reveal an ability to adapt to difficult environmental conditions (Lacoul and Freedman, 2006). In the river-lake system of the lake district landscape, the Eurasian water milfoil, $M$. spicatum, occurring in waters of the bay, is a species which, which is adapted to the conditions of excessive calcium concentration. The presence of this species in the bay zone was correlated with the bottom sediment abundance of this component (Potasznik and Szymczyk, 2015).

Fluctuations in the water level play a significant role in regulating the growth of macrophytes. Water depth is one of the most important factors determining the division into zones, distribution and spatial arrangement of the reed, P. australis, tolerant to long-term flooding (Tóth, 2016). In the research object, this species occurred most often in all zones of the river-lake water body covered by plants, often occupying the entire area of the examined transects (ranging from 60 to $100 \%)$. The reed is a species present in rushes of water ecosystems for long periods, semi-permanently or temporarily and rhizomes of those plants contribute to decomposition of organic and inorganic matter (Meyerson et al., 2016). In almost the entire water body, the common reed $P$. australis occurred as a typical species representing swamp and water plants, with a wide ecological tolerance range. Its range in individual transects covered from 60 to $100 \%$ of the surface. The reedmace, Typha latifolia L., a characteristic species for the shores of still and slow-moving waters, growing on the muddy substrate, abundant in organic matter, was also very frequent. Its presence accounted for about $10 \%$ coverage of the area. Additionally, the lesser reedmace, Typha angustifolia L., was also present in the bay part. As with the reedmace, it is a species typical for still or slow-moving water, growing on loamy or sandy ground. In Lake Symsar, it was present in its eastern part, featuring large land denivelations. In addition, the Eurasian water milfoil, M. spicatum, a species that is freefloating or anchored on the bottom and typical for waters rich in calcium, was present in the bay part. In the recreational part, near the beach, the small water lily $N$. alba L., was found, which is a protected species, growing in shallow still waters up to two meters deep with sandy and silty bottom, i.e. typical for littoral zones of water bodies. The forest part featured the swamp horsetail Equisetum fluviafile L., typical for rushes located in the vicinity of forests.

$P$. australis transports oxygen through its stalks to its rhizomes and roots, and then to the zone of sediments around the root resulting an oxidized microenvironment in the rooting and contributing to loosening of the substrate structure by root overgrowth, which increases the coefficient of filtration, while a lower density of sediments makes them a good sorbent. Oxygen diffusion and oxygen access to the roots are affected by less densification. Under anaerobic conditions deposits become a major source of phosphorus. Additionally, roots act as biocatalysts, permitting the optimum growth of microorganisms in the ground and water zone, after which the components taken up by the plant are built into its cells (Todorovics et al., 2005). In turn, Typha latifolia is a typical invasive species, quickly expanding its range and is capable of creating monospecific habitats, which often displace native species (Selbo and Snow, 2004). Additionally, the literature emphasizes the role of this species as an effective protective barrier for bottom sediments and water (Parzych et al., 2016). Nutrients and metals taken up by the aquatic plants are accumulated in their roots, stems and leaves. The species demonstrates a high ability to assimilate 
heavy metals, with tolerance to their increased concentrations without severe physiological damage. The bioaccumulation rate in plants can depend on the species and environmental load (Shafi et al., 2015).

The presence of some species of plants can be correlated not only with morphometric conditions, i.e. depth, but also the abundance of nutrients in sediments (Johnson and Ostrofsky, 2004). One example is the Eurasian water-milfoil, which inhabits sediments rich in calcium. The intensity of component removal, including metals, from an aquatic environment depends on $\mathrm{pH}$, redox status and the nature of the contamination (Mishra et al., 2008; Branković et al., 2012). For instance, Typha can grow in low $\mathrm{pH}$ levels (Brix et al., 2002). In turn, the lead contents in aquatic plants were inversely correlated with the reaction of bottom deposits, where lower $\mathrm{pH}$ values determined its higher contents in rushes. Jackson et al. (1993) demonstrated that low pH of bottom sediments and mild redox conditions increased bioavailability of some metals by aquatic plants. In our research, this dependency is observed for the nitrogen content in plants. The process of interaction between aquatic plants and sediments consists in oxygen transport through the stalks to rhizomes and roots, which results in the creation of an aerobic zone around the roots. In this zone, as a result of the aerobic bacteria activity, carbon compounds are released, which is followed by the process of ammonium nitrogen nitrification. Outside the roots, in the anaerobic zone, the process of dephosphorization and denitrification occurs. This results in proliferation of microorganisms in the substrate. Oxygen transport to roots results in increasing the aerobic decomposition of organic matter (Brix, 1994).

The accumulation of metals by aquatic plants and in bottom sediments is a response to progressing urbanization (Rzymski et al., 2014). According to Njuguna et al. (2017), industrial development, household sewerage, agricultural activity and waste are the factors that contribute to this phenomenon to the largest extent. On the basis of the conducted research, it was observed that plants in specific zones accumulated individual metals with various intensity. In plants occurring along the course of the Symsarna River, the nutrients accumulating in the highest amounts included nitrogen and phosphorus and the metals cadmium and chromium. Similar to research of KuriataPotasznik et al., (2016) in the recreational zone, most of the determined components under analysis were accumulated in macrophytes, which resulted from anthropogenic factors, including the inflow of domestic wastewater. The location of macrophytes in the water body may depend on exposure to wind and waves, depth of the water body, water clarity, abundance of nutrients in water and sediments. However, the greatest impact on the abundance of nutrients was found for the type of substrate on which the plants grow. Bottom sediment is an underestimated factor affecting the efficiency of nutrient removal by plants (Tang et al., 2017).

Macrophytes in the water body can transform solar energy reaching the lake ecosystem ( $\mathrm{Li}$ et al., 2014), as well as metabolize various pollutants suspended in the water column (Wang et al., 2013) through assimilation by aquatic plants (Li et al., 2014). During their growth, plants can accumulate nutrients by direct uptake, but they also can absorb it directly from sediments through their roots anchored in the bottom (Carvalho et al., 2015). The research by Potasznik et al. (2014) suggests that during the period of vegetation involving intensive growth of macrophytes in the water body, nutrient takeout outside the area of the water catchment area is reduced. This shows an environmentally important role of macrophytes which, by retaining some pollution, can reduce its outflow from the drainage area, which can mitigate the negative effects of human activity on water ecosystems (Wang et al., 2014).

\section{Conclusion}

The greatest effect on the accumulation of an excessive amount of substances like nutrients and heavy metals occurring in the water ecosystem of the river and lake system seems to be demonstrated by properties of the bottom sediments, mainly their granulometric composition, and, to a lower extent, the organic matter content and $\mathrm{pH}$. The granulometric composition of sediments, with the domination of very fine fractions, plays a very important role in stabilising sediments. These sediments create a dense structure, preventing bottom erosion by the water movement. This results in retaining the nutrients at the bottom, and reduces their uptake by the plants. On the other hand, it was demonstrated that aquatic plants can have an effect on the fraction size in sediments, particularly near the outlet of the river to the water body. Since the granulometric composition of sediments in the river-lake system is determined by the river flowing through the lake, it has an indirect effect on assimilation of components from the bottom by aquatic plants.

The river-lake system is a specific trap for biogenes, as due to their accumulation in sediments or aquatic plants, it reduces their penetration outside the system. Identifying factors affecting the assimilation of nutrients by macrophytes, such as the properties of bottom sediments, can permit in the future creating controlled conditions leading to contamination capture, simulating the operation of a river and lake system.

Acknowledgments. This study was financially supported by the National Scientific Center, Poland, Grant No. 2015/19/ N/ST10/01532.

\section{References}

Bartoszek L. 2007. Wydzielanie fosforu z osadów dennych. Zeszyty Naukowe Politechniki Rzeszowskiej 240: 5-21 (in Polish).

Branković S, Pavlović-Muratspahić D, Topuzović M, Glišić R, Milivojević J, Đekić V. 2012. Metals concentration and accumulation in several aquatic macrophytes. Biotechnol Biotechnol Equip 26: 2731-2736.

Brix H. 1994. Functions of macrophytes in constructed wetlands. Water Sci Technol 29: 71-78.

Brix H, Dyhr-Jensen K, Lorenzen B. 2002. Root-zone acidity and nitrogen source affects Typha latifolia L. growth and uptake kinetics of ammonium and nitrate. J Exp Bot 53: 2441-2450.

Carvalho C, Hepp LU, Dalma-Silva C, Albertoni EF. 2015. Decomposition of macrophytes in a shallow subtropical lake. Limnologica 53: 1-9.

Connell DW, Miller GJ. 1984. Chemistry and ecotoxicology of pollution, John Wiley \& Sons: New York, NY, USA.

Czamara A, Czamara W. 2008. Heavy metal in the Msciwojów Reservoir ecological system. Infrastruktura i Ekologia Terenów Wiejskich 9: 283-296 (in Polish). 
Duarte CM, Kalff J. 1988. Influence of Lake Morphometry on the response of submerged Macrophyte to sediment fertilization. Can J Fish Aquat Sci 45: 216-221.

Du Laing G, Van Ryckegem G, Tack FM, Verloo MG. 2006. Metal accumulation in intertidal litter through decomposing leaf blades, sheaths and stems of Phragmites australis. Chemosphere 63: 1815-1823.

Ganesh KS, Sundaramoorthy P, Nagarajan M. 2015. Organic soil amendments: potential source for heavy metal accumulation. World Sci News 16: 28-39.

Glińska-Lewczuk K. 2005. Oxbow lakes as biogeochemical filters for nutrient outflow from agricultural areas. In: Heathwaite L, Webb B, Rosenberry D, Weaver D, Hayash M, eds. Dynamics and Biogeochemistry of River Corridors and Wetlands. Proceedings of symposium S4 held during the Seventh IAHS Scientific Assembly at Foz do Iguacu, Brazil, April. IAHS Publ 294: 55-65.

Glińska-Lewczuk K. 2006. Effect of land use and lake presence on chemical diversity of the Łyna river system. Pol J Environ Stud 15: 259-269.

Huang W, Chen Q, Ren K, Chen K. 2015. Vertical distribution and retention mechanism of nitrogen and phosphorus in soils with different macrophytes of a natural river, mouth wetlands. Environ Monit Assess 187: 97.

Jackson LJ, Kalff J, Rasnnussen JB. 1993. Sediment pH and redox potential affect the bioavailability of $\mathrm{Al}, \mathrm{Cu}, \mathrm{Fe}, \mathrm{Mn}$, and $\mathrm{Zn}$ to rooted aquatic macrophytes. Can J Fish Aquat Sci 50: 143-148.

Jensen S. 1979. Classification of lakes in southern Sweden on the basis of their macrophyte composition by means of multivariate methods. Vegetation 39: 129-146.

Jespersen DN, Sorrell BK, Brix H. 1998. Growth and root oxygen release by Typha latifolia and its effects on sediment methanogenesis. Aquat Bot 61: 165-180.

Jin L, Whitehead PG, Heppell CM, Lansdown K, Purdie DA, Trimmer M. 2016. Modelling flow and inorganic nitrogen dynamics on the Hampshire Avon: linking upstream processes to downstream water quality. Sci Total Environ 572: 1496-1506.

Johnson RR, Ostrofsky ML. 2004. Effect of sediment nutrients and depth on small-scale spatial heterogeneity of submersed macrophyte communities in Lake Pleasant Pensynwalia. Can J Fish Aquat Sci 61: 1493-1502.

Kisson LTT, Jacob DL, Hanson MA, Herwig BR, Bowe SE, Otte ML. 2013. Macrophytes in shallow lakes: relationships with water, sediment and watershed characteristics. Aquat Bot 109: 39-48.

Koch EW. 2001. Beyond light: physical, geological, and geochemical parameters as possible submersed aquatic vegetation habitat requirements. Estuaries 24: 1-17.

Kolada A, Ciecierska H. 2009. Wytyczne do prowadzenia badań terenowych oraz sposobu zestawiania i przetwarzania danych o makrolitach w jeziorach. Warszawa: IOS - UWM, $22 \mathrm{p}$ (in Polish).

Kuriata-Potasznik A, Szymczyk S, Skwierawski A, Glińska-Lewczuk K, Cymes I. 2016. Heavy metal contamination in the surface layer of bottom sediments in a flow-through lake: a case study of lake symsar in northern poland. Water 8: 358.

Lacoul P, Freedman B. 2006. Environmental influences on aquatic plants in freshwater ecosystems. Environ Rev 14: 89-136.

Lakatos G, Kiss M, Mészáros I. 1999. Heavy metal content of common reed (Phragmites australis/Cay./Trin. ex Steudel) and its periphyton in Hungarian shallow standing waters. Biology, Ecology and Management of Aquatic Plants. Netherlands: Springer, pp. 47-53.

Li C-H, Wang B, Ye C, Ba Y-X. 2014. The release of nitrogen and phosphorus during the decomposition process of submerged
Macrophyte (Hydrilla veticillata Royle) with different biomass levels. Ecol Eng 70: 268-274.

Madsen JD, Chambers PA, James WF, Koch EW, Westlake DF. 2001. The interaction between water movement, sediment dynamics and submersed macrophytes. Hydrobiologia 444: 71-84.

Meyerson LA, Cronin JT, Pyšek P. 2016. Phragmites australis as a model organism for studying plant invasions. Biol Invasions 18: 2421-2431.

Mishra VK, Upadhayaya AR, Pandey SK, Tripathi BD. 2008. Heavy metal pollution induced due to coal mining effluent on surrounding aquatic ecosystem and its management through naturally occurring aquatic macrophytes. Bioresour Technol 99: 930-936.

Njuguna SM, Yan X, Gituru RW, Wang Q, Wang J. 2017. Assessment of macrophyte, heavy metal, and nutrient concentrations in the water of the Nairobi River, Kenya. Environ Monit Assess 189: 454.

Obolewski K. 2002. Epiphytic organisms (periphyton) inhabiting reed Phragmites australis, broadleaf cattail Typha latifolia and artificial substrate in the Pomeranian Lubowidzkie Lake-preliminary study. Stupskie Prace Przyrodn Limnol 1: 71-82 (in Polish).

Obolewski K. 2005. Organizmy poros lowe (perifiton) zasiedlające wiosną trzcinęphragmites australis i pałkę Typha latifolia w jeziorze Raduńskie Dolne - badania wstępne. Stupskie Prace Biologiczne 2: 37-48 (in Polish).

Obolewski K, Skorbiłowicz E, Skorbiłowiz M, Glińska-Lewczuk K, Astel AM, Strzelczak A. 2011. The effect of metals accumulated in reed Phagmites australis on the structure of peryfiton. Ecotoxical Environ Saf 74: 558-568.

Pachuta K, Oglęcki P. 2001. Wstępna inwentaryzacja flory i fauny Jeziora Imielińskiego w Warszawie w aspekcie ochrony jego walorów przyrodniczo-krajobrazowych. Zeszyty Problemowe Postepów Nauk Rolniczych 478: 495-507 (in Polish).

Pajević S, Kevrešan Ž, Radulović S, Radnović D, Vučković M, Matavulj M. 2003. Aquatic macrophytes - role in monitoring and remediation of nutrients and heavy metals. ISIRR. Section III.

Parsons CT, Rezaneshad F, O'Connell DW, van Cappellan P. 2017. Sediment phosphorus speciation and mobility under dynamic redox condition. Biogeosciences 14: 3585-3602.

Parzych A, Cymer M, Macheta K. 2016. Leaves and roots of Typha latifolia and Iris pseudacorus as bioindicators of contamination of bottom sediments by heavy metals. Limnol Rev 16: 77-83.

Pełchaty M, Promin E. 2015. Rola ros linnos ci wodnej i szuwarowej w funkcjonowaniu jezior. Ocena stanu ich wód. Studia Limnologica of Telmatologica 9: 25-34 (in Polish).

Potasznik A, Szymczyk S. 2015. Magnesium and calcium concentrations in the surface water and bottom deposits of a river-lake system. J Elementol 20: 677-692.

Potasznik A, Szymczyk S. 2016. Does inflow of water river shape the nutrient content of lake sediments? J Elementol 21: 471-484.

Potasznik A, Szymczyk S, Sidoruk M, S witajska IJ. 2014. Role of Lake Symsar in the reduction of phosphorus concentration in surface runoff from agricultural lands. J Water Land Dev 20: 39-44.

Rzymski P, Niedzielski P, Klimaszyk P, Poniedziałek B. 2014. Bioaccumulation of selected metals in bivalves (Unionidae) and Phragmites australis inhabiting a municipal water reservoir. Environ Monit Assess 186: 3199-3212.

Sasmaz A, Obek E, Hasar, H. 2008. The accumulation of heavy metals in Typha latifolia L. grown in a stream carrying secondary effluent. Ecol Eng 33: 278-284.

Selbo SM, Snow AA. 2004. The potential for hybridization between Typha angustifolia and Typha latifolia in a constructed wetland. Aquat Bot 78: 361-369. 
Shafi N, Pandit AR, Kamili AN, Mushtag B. 2015. Heavy metal accumulation by azollapinnata of dal lake ecosystem, India. $J$ Environ Prot Sustain Dev 1: 8-12.

Skorbiłowicz E, Skorbiłowicz M, Malinowska D. 2016. Accumulation of heavy metals in organs of aqueous plants and its association with bottom sediments in bug river (poland). J Ecol Eng 17: 295-305.

Szafran K. 2003. Metale cięzkie w osadach dennych trzech płytkich jezior Łęczycko-Włodawskich. Acta Agrophys 1: 329-337 (in Polish).

Szmeja J. 2006. Przewodnik do badań roslinnosci wodnej, Gdańsk: Wydawnictwo Uniwersytetu Gdańskiego, 1-407 (in Polish).

Tang Y, Harpenslager SF, van Kempen MM, et al. 2017. Aquatic macrophytes can be used for wastewater polishing but not for purification in constructed wetlands. Biogeosciences 14: 755.

Ter Braak CJF, SmilauerP. 2002. CANOCO reference manual and canodraw for windows user's guide: software for canonical community ordination (version 4.5). Ithaca, NY, USA: Microcomputer Power, $500 \mathrm{p}$.

Todorovics C, Garay TM, Bratek Z. 2005. The use of the reed (Phragmites australis) in wastewater treatment on constructed wetlands. Acta Biologica Szegediensis 49: 81-83.
Tóth VR. 2016. Reed stands during different water level periods: physico-chemical properties of the sediments and growth of Phragmites australis of Lake Balaton. Hydrobiologia 778: 193-207.

Wang Y, Li Z, Zhou L, Feng L, Fan N, Shen J. 2013. Effects of macrophyte-associated nitrogen cycling bacteria on denitrification in the sediments of the eutrophic Gonghu Bay, Taihu Lake. Hydrobiologia 700: 329-341.

Wang Z, Yao L, Lin G, Liu W. 2014. Heavy metals in water, sediments and submerged macrophytes in ponds around the Dianchi Lake, China. Ecotoxicol Environ Saf 107: 200-206.

Wojewódzki Inspektorat Ochrony S rodowiska. 2012. Raport o stanie srodowiska województwa warmińsko-mazurskiego w 2011 roku. Biblioteka Monitoringu S rodowiska, praca zbiorowa pod kierunkiem Danuty Budzyńskiej, 35 p (in Polish).

Yu Q, Wang HZ., Li Y, Shao JC, et al. 2015. Effects of high nitrogen concentration on the growth of submersed Macrophyte at moderate phosphorus concentrations. Water Res 83: 385-395.

Zerbe J, Sobczyński T, Elbanowska H, Siepak J. 1999. Speciation of heavy metals in bottom sediments of lakes. Pol J Environ Stud 8: 331-339.

Cite this article as: Kuriata-Potasznik A, Szymczyk S, Pilejczyk D. 2018. Effect of bottom sediments on the nutrient and metal concentration in macrophytes of river-lake systems. Ann. Limnol. - Int. J. Lim. 54: 1. 